\title{
The use of innovative learning methods in high educational establishments as a stage of implementation of improving the quality of the educational process
}

\section{Leyla KHAKIMOVA ${ }^{1}$, Mukhtaram LAPASOVA ${ }^{2}$, Zebiniso LAPASOVA ${ }^{3}$}

Samarkand State Medical Institute

\begin{tabular}{l} 
ARTICLE INFO \\
\hline Article history: \\
Received December 2021 \\
Received in revised form \\
15 December 2022 \\
Accepted 20 January 2022 \\
Available online \\
15 Fabray 2022 \\
\hline Keywords: \\
innovative methods and \\
forms of education, \\
direct model of education, \\
interactive model of \\
education, \\
case-study, \\
Insert method, \\
problem-solving \\
interpretation.
\end{tabular}

\section{ARTICLE INFO}

Article history:

Received December 2021

Received in revised form

15 December 2022

Accepted 20 January 2022

Keywords:

innovative methods and

forms of education

interactive model of

education,

case-study,

problem-solving

interpretation.

\begin{abstract}
The relevance of the problem of introducing innovative methods in the learning process of university students is a priority topic in the education system. At present, there is an intensive search for new forms and methods of teaching, which allows us to talk about the transition from the directive model of learning to an interactive, more productive and personalityoriented learner. The main purpose of using modern innovative technologies in the education system is to form a versatile personality capable of realizing creative potential in dynamic socio-economic conditions, both in their own life interests and in the interests of society. The use of information technology leads on the one hand to the creative and intellectual development of the student and, on the other hand, does not leave the teacher out, assuming the influence of his or her personality on the learning process, i.e. having a high level of socio-psychological competence.
\end{abstract}

2181-1415/@ 2022 in Science LLC.

DOI: https://doi.org/10.47689/2181-1415-vol3-iss1/S-pp121-125

This is an open access article under the Attribution 4.0 International (CC BY 4.0) license (https://creativecommons.org/licenses/by/4.0/deed.ru)

\section{Oliy ta'lim muassasalarida ta'lim jarayoni sifatini oshirishda innovatsion ta'lim usullaridan foydalanish}

\section{Kalit so'zlar:}

o'qitishning innovatsion

usullari va shakllari,

direktiv ta'lim modeli,

interfaol ta'lim modeli,
ANNOTATSIYA

Universitet talabalarini o'qitish jarayonida innovatsion usullarni joriy etish muammosining dolzarbligi ta'lim tizimidagi ustuvor mavzudir. Hozirgi vaqtda o'qitishning direktiv modeldan interaktiv, samaraliroq va shaxsga yo'naltirilgan ta'lim

\footnotetext{
1 Senior lecturer, Samarkand State Medical Institute. Samarkand, Uzbekistan.

${ }^{2}$ Assistant, Samarkand State Medical Institute. Samarkand, Uzbekistan.

${ }^{3}$ Senior lecturer, Samarkand State Medical Institute. Samarkand, Uzbekistan
} 
keys-stadi, Insert usuli, muammoli bayon. modeliga o'tish haqida gapirish imkonini beradigan o'qitishning yangi shakllari va usullarini jadal izlash ishlari olib borilmoqda. Ta'lim tizimida zamonaviy innovatsion texnologiyalardan foydalanishning asosiy maqsadi ham o'zining hayotiy manfaatlari, ham jamiyat manfaatlari yo'lida dinamik ijtimoiyiqtisodiy sharoitlarda ijodiy salohiyatni ro'yobga chiqarishga qodir ko'p tarmoqli shaxsni shakllantirishdan iborat. Axborot texnologiyalaridan foydalanish, bir tomondan, o'quvchi shaxsining ijodiy-intellektual rivojlanishiga olib keladi, ikkinchi tomondan, o'qituvchini chetda qoldirmaydi, uning shaxsiyatining ta'lim jarayoniga ta'sirini o'z ichiga oladi, ya'ni yuqori darajadagi ijtimoiy-psixologik kompetentsiyaning mavjudligi ushbu holatni amalga oshirishga imkon beradi.

\section{Использование инновационных методов обучения в высших учебных заведениях как ступень реализации улучшения качества учебного процесса}

\author{
Ключевые слова: \\ инновационные методы и \\ формы обучения, \\ директивная модель \\ обучения, \\ интерактивная модель \\ обучения, \\ кейс-стади, \\ метод Insert, \\ проблемное изложение.
}

\begin{abstract}
АННОТАЦИЯ
Актуальность проблемы внедрения инновационных методов в процесс обучения студентов вузов является приоритетной темой в системе образования. В настоящее время ведется интенсивный поиск новых форм и методов преподавания, что позволяет говорить о переходе обучения от директивной модели к интерактивной, более продуктивной и ориентированной на личность обучаемого. Основной целью использования современных инновационных технологий в системе образования является формирование разносторонне развитой личности, способной реализовать творческий потенциал в динамичных социально-экономических условиях, как в собственных жизненных интересах, так и в интересах общества. Использование информационных технологий приводит с одной стороны к творческому и интеллектуальному развитию личности студента и, с другой стороны, не оставляет в стороне преподавателя, предполагая влияние его личности на процесс обучения, то есть наличия у него высокого уровня социальнопсихологической компетентности.
\end{abstract}

At present, in order to implement the programme for improving the quality of the higher education system, we are searching for such methods that would be able to form a specialist within the university that would meet the requirements of the time. One of such methods is innovative technologies aimed at the development of analytical and creative abilities of an individual. This creates the most favourable conditions for combining the educational process with the research work of students.

The rapid development of modern society, economy and other spheres of human life requires the training of personnel able to quickly navigate in any situation, find not only the best solution to the problem, but also the ability to use the acquired knowledge, skills and abilities in practice. 
Traditional education, focused on the formation of knowledge, skills and abilities in the subject area, is increasingly lagging behind the modern requirements. Education today should be based not so much on academic disciplines as on ways of thinking and doing things. It is necessary not only to produce high-level specialists, but also to include them in the development of new technologies, to adapt them to the conditions of the specific production environment and to make them capable of making new decisions. This is one of the main prerequisites for organizing an educational process built on qualitatively new principles, means, methods and technologies that differ from traditional ones. The experience in implementing new forms and methods of training allows us to conclude that the main direction of intensification of the educational process is the convergence of educational and professional activities.

The following requirements are imposed on innovative learning technologies: dialogicality, activity-creative character, focus on supporting individual development of a student, providing students with the necessary space for making independent decisions, choosing the content and ways of learning and behaviour [1]. Interactive learning model is based on the introduction of innovative methods into the learning process: problem presentation method, presentation, discussions, case study, group work, brainstorming method, critical thinking method, quizzes, mini-studies, business and role playing games, Insert method (method of individual notes when students write a 7-10-minute associative essay), blitz questioning method, questionnaire method. The process of information transfer itself is built on the principle of teacher-student interaction. It implies greater activity of the learner, his/her creative rethinking of the received information. The main criteria of interactive model of education: possibility of informal discussion and free presentation of material, less number of lectures and more seminars, student's initiative, presence of group tasks, which require collective efforts, constant control during the semester, performance of written works. The priority principle of higher education system is the principle of taking into account the interests of the learner. In this regard, university teachers are faced with the task of developing and implementing such methods and techniques of teaching, which would be aimed at activation of students' creative potential, their desire to learn.

The necessity and advantage of transition to the use of innovative technologies in higher education system is that they contribute to socialization of a student in the process of learning and after learning, require from a teacher to organize the educational space and establish qualitatively new relationship of a teacher and a student. Innovative technologies are focused on obtaining a specific result - acquisition of skills and competencies in the process of activity. The use of innovative technologies makes it possible to achieve educational effects characterized by the assimilation of the maximum amount of knowledge, maximum creativity and a wide range of practical skills and abilities of the learner.

The purpose of interactive methods in teaching is to create a comfortable learning environment in which the student feels intellectually competent and successful, which makes the learning process itself effective. In other words, interactive learning is primarily dialogue-based learning, in which there is interaction between the student and the teacher, as well as between the students themselves. The objectives of interactive learning can be grouped as follows: to increase students' interest in the discipline and self-education; to bring learning closer to the practice of everyday life (by developing 
effective communication skills, adapting to rapidly changing living conditions, increasing psychological stress-resistance, teaching conflict resolution skills), i.e. to develop social and professional skills; to teach how to acquire new sociological knowledge; to effectively absorb the material taught; to awaken students' interest and enthusiasm in the world of work.

Education should become an interesting and engaging process that promotes personal and professional growth of a person, rather than a formal procedure for obtaining a diploma. In the context of "classical" education, the teacher is the sender of information and the student is the receiver. In such a case, the "chalk-and-talk" method, i.e. "chalk-and-talk", is often used. This is a popular method that has been used for many decades as an educational strategy in many educational institutions. In such cases, the teaching mode tends to be passive and learners play a minor role in their learning process [3].

Traditional educational approaches have led to a mismatch between what is taught to students in HEIs and what is needed to become an in-demand specialist. Thus, innovative technologies offer us to use such a method as problem-based learning, which is based on problem solving with the help of real-world problems. The main methodological innovations are also related to the use of interactive forms and methods of learning. The introduction of such forms of learning is one of the most important directions of improving student training in a modern university. Students more easily absorb, understand and remember the material they have studied through their active involvement in the learning process.

As a result, the use of information technology leads, on the one hand, to creative and intellectual development of the student's personality and, on the other hand, does not leave the teacher aside, assuming the influence of his/her personality on the learning process, i.e. having a high level of socio-psychological competence.

The leading role of innovative technologies implies forming a welcoming atmosphere, creating a positive attitude towards learning through individual attitude towards each student. The methods used in modern innovative technologies are aimed at increasing the level of motivation for learning activities, so contribute to the formation of a high level of development of students on the basis of their inclusion in a constantly increasing activity with the active support of the teacher. Various methods of modern innovative technologies (e.g. constant repetition, creating a problematic situation, differential approach, work with gifted students, etc.) are used to build the learning process in a way that creates conditions for systematisation of knowledge, development of cognitive scheme of thinking, good knowledge of theoretical material and cultivation of self-esteem. Innovative technologies lead to a change of priorities in the activity of the teacher himself/herself: not to teach, but to create conditions for independent acquisition of knowledge.

Therefore, the integral properties of innovative technology are its integrity, optimality, effectiveness, and applicability in real conditions. Thus, innovation technology in the development of modern higher education system acts as a part of science and explores the most rational ways of learning, and as a system of ways, principles and regulators used in learning, and as a real learning process. The use of different methods in innovative technology fills the educational process with innovative content, which ensures the improvement of the quality of education in higher education institutions. 
The introduction of innovative technologies in educational activities will ultimately lead to an improvement in the quality of training of future specialists. In turn, improving the quality, accessibility, efficiency of education, its continuous and innovative nature, increasing social mobility and activity of young people, their involvement in different educational environments make the education system an important factor in ensuring national security of the country and the growth of the well-being of its citizens.

Thus, the main distinguishing feature of interactive methods in education is that learners show initiative in the learning process, which is stimulated by the teacher from the position of a partner-assistant. The process and the result of acquiring knowledge becomes personally significant for each student, which allows developing the ability of independent problem solving.

In order to implement innovative technologies in teaching, it is first of all necessary to change the stale stereotypes and habits of the lecturers themselves, which are not facilitated by passive methods. In order to successfully implement effective forms of learning, a teacher needs to have a comprehensive set of skills and knowledge based on the use of modern innovative methods of working with students. Also, it is necessary to reorient the traditional approach of gaining knowledge to work with students, which allows them to be actively involved in independent thinking, development of mental abilities, ability to analyse, to draw conclusions, thereby improving the quality of learning.

\section{REFERENCES:}

1. Guzeev V.V. Planning Educational Outcomes and Educational Technology. Moscow: National Education, 2000.

2. Dobrynina D.V. Innovative methods of teaching university students as a means of implementing interactive learning model // Bulletin of Buryat University, No. 5, 2010. - P. 173.

3. Dudchenko V.S. Fundamentals of innovation methodology. - Moscow: Institute of sociology of RAS, 2007. - C. 150

4. Zhukov G.N. Fundamentals of General Professional Pedagogy: Textbook. Moscow: Gardariki, 2005.

5. Malikova N.R. On Some Innovative Methods of Teaching Sociology // Sotsis, 2002, - No. 2.

6. Manuilov V.F., Fedorov I.V., Blagoveschenskaya M.M. Modern Science-Intensive Technologies in Engineering Education // Innovations in Higher Technical School of Russia. - Vol. 2: Modern Technologies in Engineering MADI (GTU). - M., 2006. - C. 16-24.

7. Osmolovskaya I.M. Innovations and pedagogical practice // Narodnoe Obrazovanie. - 2010. - № 6. - C. 182-188.

8. Pedagogy and Psychology of Higher Education: Textbook for Universities / M.V. Bulanova-Toporkova. - Rostov-on-Don: Phoenix, 2002. 